\title{
A REVIEW OF BIOPESTICIDE PRODUCTS AS ECOLOGICAL ALTERNATIVE AGAINST FALL ARMYWORM (SPODOPTERA FRUGIPERDA) IN AFRICA
}

\author{
${ }^{* 1}$ Ekenwosu, J. U., ${ }^{2}$ Okorie, P. U. \& ${ }^{3}$ Ikpeama, C. \\ ${ }^{1,2,3}$ Department of Environmental and applied Biology, Faculty of Science, Imo State University Owerri, Nigeria \\ ${ }^{*}$ Corresponding Author Email: josephekenwosu@gmail.com Phone: 08062859813
}

\begin{abstract}
Spodoptera frugiperda, Fall Armyworm (FAW), poses an existential threat to farmers in Africa given their destructive effect on crops. This is essentially the case in south-eastern Nigeria where major crops such as cassava and maize are highly vulnerable to the adverse effects of the pest. This paper reviewed published work on the availability of biopesticides that can control FAW without compromising environmental sustainability. Altogether, 50 active ingredients have been identified as potential biopesticides to control fall armyworm globally, out of which 29 were described in Africa. Although there are reports of remarkable successes in the application of these organic pesticides, there is a need to identify more biopesticides and also establishing the most effective modes of application for managing the pest. This review examines possible biopesticides that may be used in controlling FAW in Africa and also provides insight for further research.
\end{abstract}

Keywords: Biopesticide, Active Ingredient, Environmental Sustainability, Pesticide

LICENSE: This work by Open Journals Nigeria is licensed and published under the Creative Commons Attribution License 4.0 International License, which permits unrestricted use, distribution, and reproduction in any medium, provided this article is duly cited.

COPYRIGHT: The Author(s) completely retain the copyright of this published article.

OPEN ACCESS: The Author(s) approves that this article remains permanently online in the open access (OA) mode.

QA: This Article is published in line with "COPE (Committee on Publication Ethics) and PIE (Publication Integrity \& Ethics)". 


\section{INTRODUCTION}

The emergence of FAW in Africa is worrisome given its destructive effect on food crops such as maize. As FAW continues to destroy economic crops, managing the pest often necessitates the usage of large quantities of chemical insecticides even when they are normally associated with environmental risks and health hazards. Though FAW originated from the Western Hemisphere, it has now become a pest of economic importance in Africa (Kalleshwaraswamy et al., 2019; Chen et al., 2019; Nagoshi et al., 2018; Otim et al., 2018; Brevault et al., 2018; Nagoshi et al., 2017). However, Goergen et al., (2016) reported the first case of FAW invasion in Nigeria. Maize is one of the staple foods in many African countries and it provides a source of income to both small and large-scale farmers. Although there have been concerns of low soil fertility, drought, and biotic stress such as pests and diseases, the arrival of FAW tends to increase these present concerns. Farmers in Africa are losing their crops to its attack at quite an alarming rate. For example, maize production loss estimates caused as a result of FAW infestations range from 50\% to 100\% (Baudron et al., 2019; Rwomushana et al., 2018). Though there have been reports on the use of technology and chemical pesticides in the control of FAW however, these reports have failed to provide a single strategy to effectively manage the pest (Oliveira et al., 2018; FOA, 2018; Burtet et al., 2017).

Maize crops are attacked by FAW at larval stages as seen in Plate 1. This is the most destructive phase in their lifecycle as they attack mostly the young leaves (Obok et al., 2020). Though the larva could also feed on maize silk and tassel tissues, their major feeding site preference is the succulent and tender leaf tissues, especially at whorl stages (CABI, 2018). Perhaps mature leaves are classified as unsuitable sites for the growth and development of the pest due to their preference for tender leaf tissues (Pannuti et al., 2016). The mouthpart of FAW larvae encourages rapid defoliation which often increases with the age of the larvae (CABI, 2018). Meanwhile, the first to third larval instar causes injuries ranging from perforations to defoliations of maize plant leaf while ribs and leaf stalks are less likely affected (CABI, 2018). However, the adult (males and females) is not destructive to host crops.

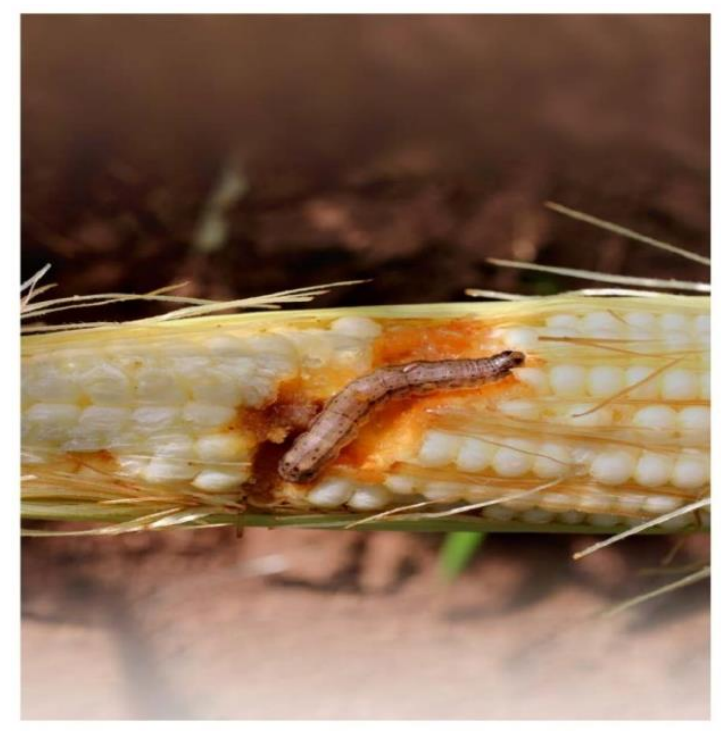

Plate 1: Larvae of fall armyworm on a maize cob Source: Centre for Agriculture and Bioscience International (CABI) 
Since the invasion of FAW in Africa, the pest has undoubtedly proven to be an existential threat to smallholders as it has continued to ravage economic crops (CABI, 2018). Despite this apparent threat to livelihood, controlling the pest using chemical pesticides cannot be reasonably justified due to environmental concerns such as heavy mental deposit on the terrestrial soil ecosystem (Misra et al., 2015). As of September 2018, FAW had invaded 44 African countries causing massive loss of crop yield (Cock et al., 2017). The projection that FAW would give rise to an annual crop yield loss of between 4.3 to 17.7 million tons of maize in Africa is frightening (Rwomushana et al., 2018). A recent evidence notes from CABI revealed that farmers in Ghana could lose $45 \%$ of maize production annually due to FAW infestation (Abrahams et al., 2017; Day et al., 2017). Similar study showed that Namibia could lose 57\% of total maize production annually due to FAW infestation (FAO, 2018). This forecast is indeed a challenge and calls for immediate action.

\section{TAXONOMY OF FALL ARMYWORM}

Fall Armyworm (FAW) is a lepidopteran pest that feeds in large numbers on the leaves, stems, and reproductive parts of more than 350 plant species causing significant damage to economic crops such as maize, rice, sorghum, sugarcane, and wheat (CABI, 2018).

\section{TAXONOMIC TREE \\ Domain: Eukaryota \\ Kingdom: Metazoa \\ Phylum: Arthropoda \\ Subphylum: Uniramia \\ Class: Insecta \\ Order: Lepidoptera \\ Family: Noctuidae \\ Genus: Spodoptera \\ Species: Spodoptera frugiperda}

\section{BIOLOGY AND ECOLOGY OF FALL ARMYWORM}

Eggs are laid at night on the leaves of the host plant stuck to the lower surface of the leaves in tight clusters of 100300 and sometimes in two layers usually covered with a protective layer of abdominal bristles (CABI, 2018). Hatching requires 2-10 days (usually 3-5) (FAO, 2018). The mortality rate following emergence may be high in some cases due to climatic factors and attacks by predators, parasitoids, and pathogens (CABI, 2018). During the first instar stage, young larvae move to the whorl and feed on the underside of the young leaves causing a characteristic 'windowing' effect (CABI, 2018). However, in the second and third instar stages, larvae are usually cannibalistic, and thus one or two larvae per whorl (Obok et al., 2020). The rate of larval development through the six instars is controlled by a combination of diet and temperature conditions and usually takes 14-21 days. Larger larvae are nocturnal unless they enter the armyworm phase when they swarm and disperse, seeking other food sources. Pupation takes place inside a loose cocoon in an earthen cell but has also been observed in the kernels of the maize cob or rarely between leaves on the host plant and a period of 9-13 days are required for development. Adults emerge at night, and they typically use their natural pre-oviposition period of 3-4 days to fly for many kilometres before they settle to oviposit, sometimes migrating for long distances. In the migratory habit, moths can migrate over $500 \mathrm{~km}$ (300 miles) before oviposition. 
The female normally deposits most of her eggs during the first 4-5 days of life, but some oviposition continues to occur for up to 3 weeks (CABI, 2018). On average, adults live for 12-14 days (CABI, 2018; FAO, 2018). Fig 1 shows the developmental stages of FAW.

\section{(ab) $\mathrm{CABI}$}

\section{Fall Armyworm: Life cycle and damage to Maize}

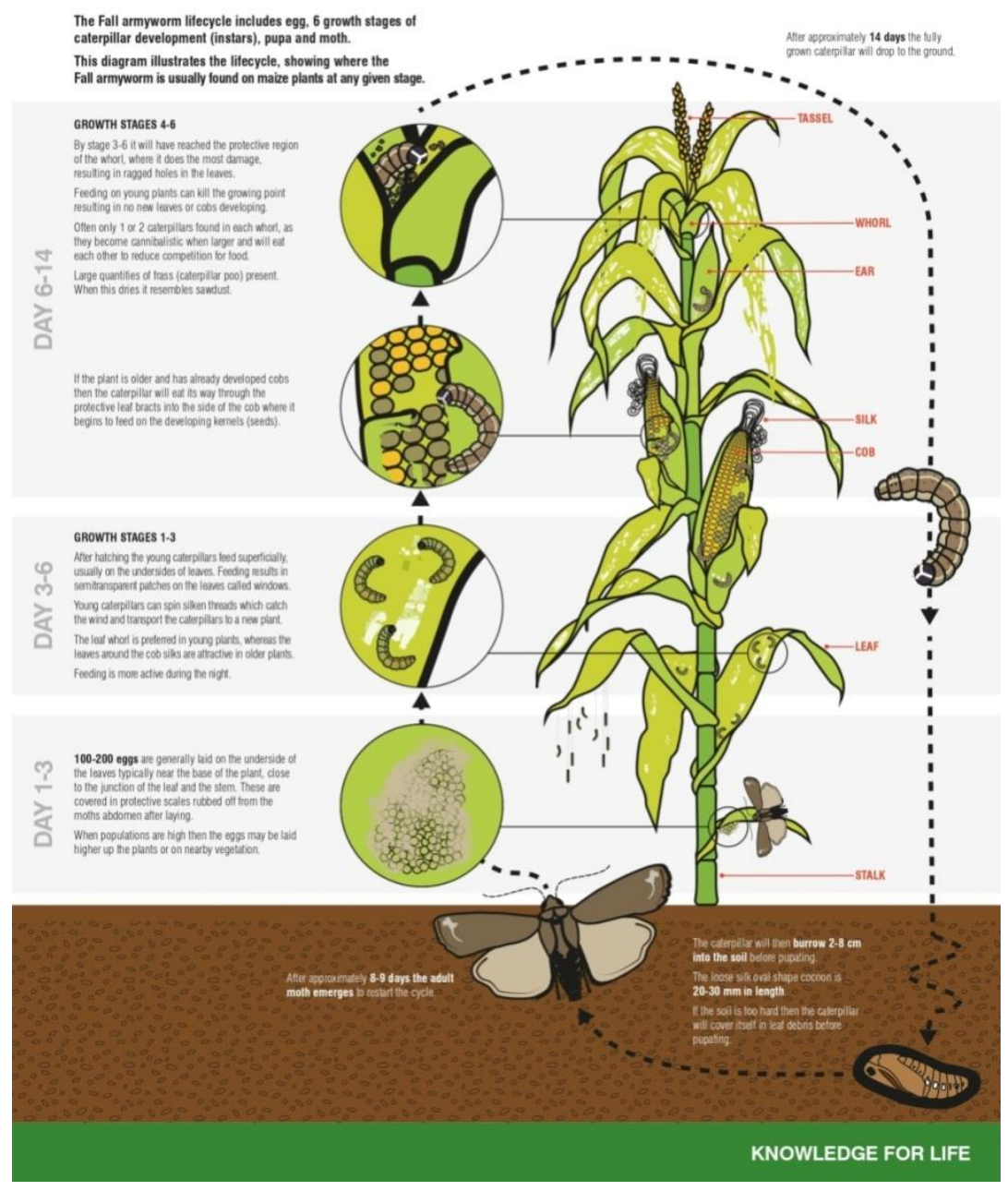

Figure 1: FAW life cycle

Source: Centre for Agriculture and Bioscience International (CABI)

\section{BIOPESTICIDES FOR PEST MANAGEMENT}

The use of plant-derived pesticides (commonly called "botanicals") in pest management is a cultural practice of most African farmers. It could provide a potential arsenal against FAW in Africa. The mode of action of botanical pesticides is broad and ranges from repellency, knock-down, larvicidal to anti-feedant, moulting inhibitors, and growth regulation. They have a broad-spectrum activity with very little or no mammalian toxicity. However, some botanicals like tobacco extracts are highly toxic to pests and humans (Ashishie and Ashishie (2018). Smallholders normally use 
water to extract bioactive ingredients as a concoction after grinding plant materials. Essential oils are also used at times. A review of literature in search of biopesticides that are effective against FAW showed that a total of 29 active ingredients (AI) have so far been identified in Africa of which Tunisia, Kenya, and South Africa have the highest number of registered biopesticide products as well as active ingredients (Fig 2) (Bateman et al., 2018). Tunisia has 70 products and 11 AI, Kenya has 85 products and 20 AI, while South Africa has 61 products and 18 AI (Bateman et al., 2018).

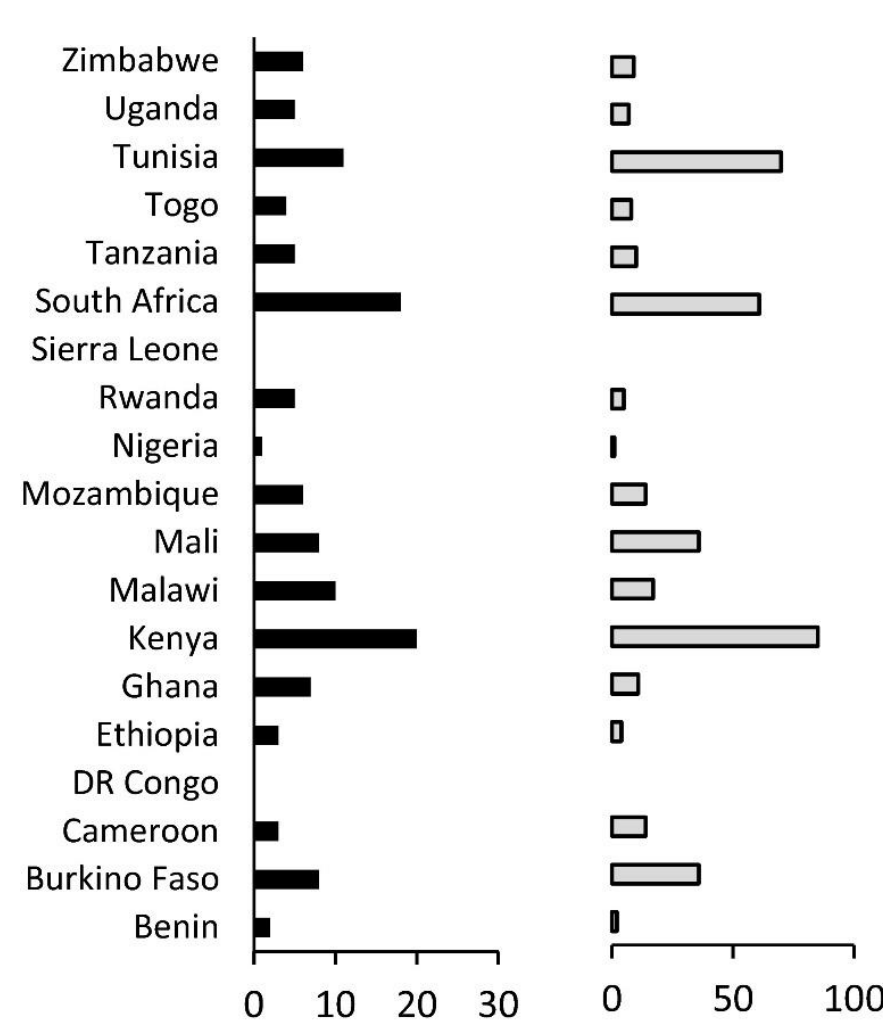

No. of biopesticide Al $\quad \square$ No. of products registered

Figure 2: Registered biopesticide active ingredients (left, dark) and corresponding products (right, pale) in 19 countries in Africa.

Source: Bateman et al., 2018 
Table 1: Overview of biopesticide active ingredients (AI)

\begin{tabular}{|c|c|c|c|c|}
\hline \begin{tabular}{|l} 
Registered for \\
field use \\
against FAW \\
or other \\
Lepidoptera \\
in our survey
\end{tabular} & $\begin{array}{l}\text { Reported effective } \\
\text { against FAW in field } \\
\text { trials in native } \\
\text { range; field trials } \\
\text { and evaluation } \\
\text { needed in Africa }\end{array}$ & $\begin{array}{l}\text { Reported effective } \\
\text { against FAW in lab } \\
\text { bioassays; field } \\
\text { trials needed in } \\
\text { Africa }\end{array}$ & $\begin{array}{l}\text { Reported effective } \\
\text { against related } \\
\text { pests; bioassays } \\
\text { needed for FAW } \\
\text { followed by } \\
\text { field trials if } \\
\text { justified }\end{array}$ & \begin{tabular}{|l} 
Not \\
recommended \\
for follow-up \\
on available \\
information \\
(at this time)
\end{tabular} \\
\hline Not registered & & & & Ethyl pulmitate \\
\hline \multirow{12}{*}{$\begin{array}{l}\text { Registered } \\
\text { outside } \\
\text { sub-Saharan } \\
\text { Africa }\end{array}$} & \multirow[t]{12}{*}{$\begin{array}{l}\text { Spodoptera frugiperda } \\
\text { NPV }\end{array}$} & \multirow[t]{12}{*}{$\begin{array}{l}\text { Dysphana } \\
\text { ambrosiodes }\end{array}$} & \multirow{12}{*}{$\begin{array}{l}\text { Garlic oil } \\
\text { Allyl isothiolyanate } \\
\text { Sucrose octanoate }\end{array}$} & $\begin{array}{l}\text { 2-phenylethyl- } \\
\text { propanoate }\end{array}$ \\
\hline & & & & $\begin{array}{l}\text { Anagrapha- } \\
\text { fallipera NPV }\end{array}$ \\
\hline & & & & \begin{tabular}{|l|} 
Chromobacterium \\
subtsugae. \\
\end{tabular} \\
\hline & & & & Cinnamaldehyde \\
\hline & & & & Cryolite \\
\hline & & & & $\begin{array}{l}\text { d-glucitol, } \\
\text { octanoate }\end{array}$ \\
\hline & & & & $\begin{array}{l}\text { GS-omega/kappa- } \\
\text { Hxtx-Hv1a }\end{array}$ \\
\hline & & & & $\begin{array}{l}\text { Helicoverpa zea } \\
\text { NPV }\end{array}$ \\
\hline & & & & $\begin{array}{l}\text { Isaria } \\
\text { fumosorosea }\end{array}$ \\
\hline & & & & $\begin{array}{l}\text { Beet armyworm } \\
\text { NPV }\end{array}$ \\
\hline & & & & $\begin{array}{l}\text { Potassium salts of } \\
\text { fatty acids }\end{array}$ \\
\hline & & & & \begin{tabular}{|l|} 
S-methroprene \\
Sovhean il
\end{tabular} \\
\hline \multirow{7}{*}{$\begin{array}{l}\text { Registered } \\
\text { within } \\
\text { sub-Saharan } \\
\text { Africa }\end{array}$} & \multirow{7}{*}{$\begin{array}{l}\text { Azadirachtin } \\
\text { (neem products) } \\
\text { Bacillus thuringiensis } \\
\text { Lufenuron } \\
\text { Methoxy fenozide } \\
\text { Oxymaytine } \\
\text { Pyrethrins } \\
\text { Sex pheromones } \\
\text { Silicon dioxide } \\
\\
\text { Spinetoram } \\
\text { Spinosad } \\
\text { Trichogramma spp }\end{array}$} & \multirow{7}{*}{$\begin{array}{l}\text { Beauveria bassiana } \\
\text { Matrine }\end{array}$} & \multirow{7}{*}{\begin{tabular}{|l} 
Capsaicin \\
Kaolin clay \\
Maltodextrin \\
Metarhizium \\
anisopliae \\
Orange oil
\end{tabular}} & Borax \\
\hline & & & & Canola oil \\
\hline & & & & \begin{tabular}{|l} 
Citric acid \\
\end{tabular} \\
\hline & & & & $\begin{array}{l}\begin{array}{l}\text { Emamectin } \\
\text { benzoate }\end{array} \\
\end{array}$ \\
\hline & & & & \begin{tabular}{|l|} 
Eugenol \\
\end{tabular} \\
\hline & & & & \begin{tabular}{|l|} 
Steinernema spp \\
Sulphur
\end{tabular} \\
\hline & & & & \\
\hline
\end{tabular}

Source: Bateman et al., (2018)

An overview of biopesticide active ingredients (Table 1) revealed that orange oil which is an active ingredient extracted from (Orange plant) Citrus sinensis, has been reported effective against pests and that bioassay is needed for FAW control to be followed by field trial (Bateman et al., 2018). Altogether, a total of 50 biopesticide active ingredients have been identified and registered worldwide in the management of FAW (Bateman et al., 2018). This 
clarification becomes necessary because the list of registered biopesticides and their active ingredients in FAW management is regularly updated. Among the registered 50 active ingredients are products from 417 botanicals, 274 microbials, 271 microbial extracts, one parasitoid (Trichogramma pretiosum Riley), and two entomopathogenic nematodes Steinernema carpocapsae (Weiser) and Steinernema feltiae (Filipjev) (Bateman et al., 2018). One of the microbial biopesticides identified as a priority by Bateman et al., (2018) was baculoviruses, which are highly hostspecific, non-pathogenic to beneficial insects and other non-target organisms, and are attractive candidates for integrated pest management. Littovir (RAVAGEX), a baculovirus based product, initially developed for control of African cotton leafworm, has been tested and registered against FAW in Cameroon by Andermatt Biocontrol (CABI, 2018). Work on entomopathogenic nematodes of FAW is in progress at the University of Neuchatel (CABI, 2018). Azadirachtin (neem) has been reported to be effective against FAW in the Americas and Ghana (CABI, 2018). In Ghana, for example, three products based on Azadirachtin are already registered for use against FAW. Oxymatrine and Matrine (found in Sophora spp) are reported effective against FAW in the field and laboratory bioassays respectively in the Americas (Bateman et al., 2018). Pyrethrins (from Chrysanthemum cinerariaefolium, formerly Pyrethrum) are effective against FAW and registered in Africa, but have non-target risks that require mitigation (Bateman et al., 2018). Also, extracts from Synedrella nodiflora and Lupinus stipulatus have shown to have biological effects on mature insects of FAW (FAO, 2018). Researchers from Brazil have also demonstrated that the application of a $5 \%$ extract concentration of pequi fruit decreased the amount of damage caused by the FAW caterpillars (Souza et al., 2018).

To optimize the use of botanical extracts for FAW control, Kelita et al., (2020) screened some commonly used plant pesticides in laboratory trials to determine their toxicity against the pest. They discovered that highest larval mortality was obtained from Nicotiana tabacum (66\%) and Lippia javanica (66\%) during contact toxicity tests. Similarly, in a feeding bioassay, the authors observed that L. javanica (62\%) and N. tabacum (60\%) exhibited high larval mortality. Further field investigation where maize plants infested with FAW larvae were treated with plant extracts revealed that $N$. tabacum and L. javanica were effective at reducing foliar damage compared to the untreated control whilst the synthetic pesticide chlorpyrifos was the most effective in reducing FAW foliar damage. While investigating the efficacy of some plant extracts as storage protectants against Callosobruchus maculatus, Mojisola $e t$ al., (2016) produced a biopesticide for preserving beans and grains. They investigated and developed a plant-based biopesticide formulation using lemongrass leaves to control Callosobruchus maculatus that attack food crops in storage facilities especially maize and beans weevils. Extract from lemongrass is normally used by locals in Nigeria for treatment of malaria because of its medicinal properties (Mojisola et al., 2016).

\section{CONCLUSION}

Since the invasion of FAW in Africa, the pest has proven to be a source of concern to smallholders. The projection by Rwomushana et al., (2018) that fall armyworm would give rise to an annual crop yield loss of between 4.3 to 17.7 million tons of maize in Africa calls for immediate action to forestall this downturn as farmers livelihood is being threatened. An aggressive approach that would easily manage the invasive pest and prevent this economic forecast from transiting from the realm of theory to reality is required. While some farmers have resort to the use of chemical 
pesticides to manage FAW, environmentalists have raised concern about the negative implication of the continuous use of chemical pesticides on the terrestrial soil ecosystem. Interestingly, in an assessment of potential biopesticide options for managing fall armyworm in Africa, FAO (2018) suggested the use of plant and microbial extracts in the fight against the pest at the continental level as possible alternatives to chemical pesticides. Thus since Nigeria is one of those countries with very little data on approved biological products for the management and control of FAW in Africa, the call to intensify investigation on biopesticide to manage the pest is a call to either discover new active ingredients that can potentially get rid of it or at most variants or strains of active ingredients already registered. Although scientific treatise has highlighted the numbers of biological products and their active ingredients approved

for FAW control in Africa, there is a need for an extensive search of more potential biopesticides that could control the pest. This would provide smallholders with an easy and cost-effective means of managing FAW without compromising environmental sustainability.

\section{CONFLICT OF INTEREST}

The authors declare there is no conflict of interest regarding this publication

\section{ACKNOWLEDGEMENT}

The authors acknowledge with gratitude contributions of Prof A.N. Okere and Prof M.O.E. Iwuala. 


\section{REFERENCES}

Abrahams P., Bateman M., Beale T., Clottey V., Cock M., Colmenarez Y., Corniani N., Day R., Early R., Godwin J.L., Gomez J., Gonzalez-Moreno P., Murphy S.T., Oppong-Mensah B., Phiri N., Pratt C., Richards G., Silvestri S., and Witt A. (2017) Fall Armyworm: Impacts and implications for Africa (September 2017), CABI, UK. Outlooks on Pest Management 28(5), 196-201.

Ashishie, C.A. and Ashishie, P.B. (2018) Biopesticide, their ecological and toxicological effects (review). International journal of sciences. Volume 7. Online ISSN: 2305-3925; Print ISSN: 2410-4477 DOI:10.18483/ijSci.1736 http://www.ijsciences.com/pub/issue/2018-08/

Bateman, M. L., Roger, K. D., Belinda, L., Steve E.,Ulrich K., Matthew J. W. (2018) Assessment of potential biopesticide options for managing fall armyworm (Spodoptera frugiperda) in Africa. Journal of Applied Entomology. 2018; 142:805-819.

Baudron, F., Zaman-Allah M.A., Chaipa I., Chari N., and Chinwada P. (2019) Understanding the factors influencing fall armyworm (Spodoptera frugiperda J.E. Smith) damage in African smallholder maize fields and quantifying its impact on yield. A case study in eastern Zimbabwe. Crop Protection 120: 141-150. doi: 10.1016/j.cropro.2019.01.028

Brevault, T., Ndiaye A., Badiane D., Bal A.B., Sembene M., Silvie P., and Haran J. (2018) First records of the fall armyworm, Spodoptera frugiperda (Lepidoptera: Noctuidae), in Senegal. Entomologia Generalis. 37: 129-142. doi: 10.1127/entomologia/2018/0553

Burtet, L. M., Bernardi O., Melo A. A., Pes M.P., Strahl T.T. and Guedes J.V.C. (2017) Managing fall armyworm, Spodoptera frugiperda (Lepidoptera: Noctuidae), with $B t$ maize and insecticides in southern Brazil. Pest Management. Science. 73: 2569-2577. doi: 10.1002/ps.4660

Centre for Agriculture and Bioscience International (CABI) (2018) Crop Protection Compendium. Retrieved fromhttps://www.cabi.org/cpc/

Chen, M., Nagoshi R.N, Dhanani I, Asokan R., Mahadevaswamy H.M, Kalleshwaraswamy C.M., and Meagher R.L. (2019) Genetic characterization of fall armyworm infesting South Africa and India indicate recent introduction from a common source population. PLoS One 14(5): e0217755. doi: 10.1371/journal.pone.0217755

Cock, M. J. W., Beseh, P. K., Buddie, A. G., Cafá, G., and Crozier, J. (2017) Molecular methods to detect Spodoptera frugiperda in Ghana, and Implications for monitoring the spread of invasive species in developing countries. Scientific Reports, 7(4103), 10. https://doi.org/10.1038/s41598-017-04238-y

Day, R., Abrahams, P., Bateman, M., Beale, T., Clottey, V., Cock, M., Yelitza C., Natalia C., Regan E., Godwin J.L., Jose G., Moreno P.G., Murphy S.T., Oppong-Mensah B., Phiri, N., Pratt C., Silvestri S., Witt A. (2017) Fall Armyworm: Impacts and implications for Africa. Outlooks on Pest Management, 28(5): 196-201

Food and Agriculture Organization of the United Nations (FAO) (2018) Integrated management of the fall armyworm on maize: a guide for farmer field schools in Africa. Rome, Italy: FAO. Retrieved from http://www.fao.org/3/I8665EN/i8665en.pdf

Goergen, G., Kumar P.L., Sankung S.B., Togola A. and Tamo M. (2016) First report of outbreaks of the fall armyworm Spodoptera frugiperda (J.E. Smith) (Lepidoptera, Noctuidae), a new alien invasive 
pest in West and Central Africa. PLoS One 11(10): e0165632. doi: 10.1371/journal.pone.0165632

Kalleshwaraswamy, C. M., Asokan R., Mahadevaswamy H.M. and Sharanabasappa (2019) First record of invasive fall armyworm, Spodoptera frugiperda (J.E. Smith) (Lepidoptera: Noctuidae) on rice (Oryza sativa). India. Journal of Entomology and Zoology. Stud.7: 332-337.

Kelita P., Yolice T., Trust K., Vernon H.K., Phillip C.S., and Stephen R.B. (2020) Bioactivity of common pesticidal plants on fall armyworm larvae (Spodoptera frugiperda) Plants 2020, 9(1), 112; doi:10.3390/plants9010112 www.mdpi.com/journal/plants

Mishra, J., Tiwari, S., Singh, S., and Arora, N. K. (2015) Biopesticides: Where we stand? In N. K. Arora (Ed.), Plant microbes symbiosis: applied facets (pp. 37-75). Springer.

Mojisola, E. O., Charles, O. O., Adegoke, E. A., Kayode O. K. and Tosin O. A. (2016) Efficacy of some plant extracts as storage protectants against Callosobruchus maculatus. Journal of Biotechnology \& Biomaterials6:217 DOI: 10.4172/2155-952X.1000217

Nagoshi, R. N., Koffi D., Agboka K, Tounou K.A., Banerjee R., Jurat-Fuentes J.L. and Meagher R.L. (2017) Comparative molecular analyses of invasive fall armyworm in Togo reveal strong similarities to populations from the eastern United States and the Greater Antilles. PLoS One 12: e0181982. doi: 10.1371/journal.pone.0181982

Nagoshi, R. N., Goergen G., Tounou K.A., Agboka K., Koffi D. and Meagher R.L. (2018) Analysis of strain distribution, migratory potential, and invasion history of fall armyworm populations in northern sub-Saharan Africa. Scientific Reports. 8: 3710. doi: 10.1038/s41598-018-21954-1

Obok E., Ittah M., Udo I., Ojubi E., Ulafor J. and Umoetok S. (2020) Genetic variability and seasonal influence of fall armyworm (Spodoptera frugiperda) damage to early vegetative growth of African maize accessions in the humid tropics of southeastern Nigeria. Journal of Animal and Plant Sciences, 31(1): 2021, Page: 143-155

Oliveira, M. A., Filho F.H.I. and Thuler R.T. (2018) Eficiency of Bacillus thuringiensis in controlling the corn fall armyworm in laboratory conditions. Revista Inova Ciencia \&Tecnologia, Uberaba 4: 14-19.

Otim, M. H., Tay W.T., Walsh T.K., Kanyesigye D., Adumo S., Abongosi J., Ochen S., Serumaga J., Alibu S., Abalo G., Asea G. and Agona A. (2018) Detection of sister-species in invasive populations of the fall armyworm Spodoptera frugiperda (Lepidoptera: Noctuidae) from Uganda. PLoS One 13: 0194571. doi: 10.1371/journal.pone.0194571

Rwomushana, I., Bateman M., Beale T., Beseh P., Cameron K., Chiluba M., Klottey V., Davis T., Day R., Early R., Godwin J., Gonzalez-Moreno P., Kisiime M., Kenis M., Makale F., Mugambi I., Murphy S., Nunda W., Phiri N., Pratt C. and Tambo J. (2018) Fall armyworm: impacts and implications for Africa. Evidence note update. CABI, Wallingford, UK, pp.51 https://www.invasivespecies.org/wp-content/uploads/sites/2/2019/02/FAW-Evidence-Note-October-2018.pdf

Pannuti, L. E., Baldin E.L., Hunt T.E. and Paula- Moraes S.V. (2016) On-plant larval movement and feeding behavior of fall armyworm (Lepidoptera: Noctuidae) on reproductive corn stages. Environmental Entomology 45: 192-200. doi: 10.1093/ee/nvv159

Souza, M., Giustolin, T., Alvarenga, C., Costa, J. Aspiazú, I. (2018) Aqueous extract of pequi fruit to control Spodoptera frugiperda in corn. Arq. Inst. Biol. 85, 1-5. dx.doi.org/10.1590/1808-1657000072017 